\title{
Kajian Fetisisme Pada Keris Jawa
}

\author{
Yunita Fitra Andriana \\ Fakultas Industri Kreatif \\ Universitas Trilogi Jakarta
}

\begin{abstract}
Keris is one of many traditional weapon in Indonesia which is believed has an aesthetic side along with its superstition power. Therefore, keris collector divided into two kinds, there are collectors who collecting keris for its aesthetic elements and there are collectors who collecting keris for its aesthetic and also for its superstition power elements. Nowadays, Indonesian people still believe in existance of keris superstition power. The superstition power believed has higher value than its phisical power, which is makes keris as a valuable things that worth to be worshiped by Indonesian people. The worships that Indonesian people do to keris because of their belief for its superstition power is an anthropological fetishism.
\end{abstract}

Keywords: keris, superstition, fetishism

\section{PENDAHULUAN}

Indonesia memiliki beragam jenis senjata tradisional. Aneka senjata tersebut tidak pernah lepas dari sejarah dan filosofinya sendiri, berkaitan dengan kebudayaan dan kehidupan masyarakat di daerah dari mana senjata itu berasal. Ragam senjata tradisional tersebut memiliki berbagai perbedaan dan ciri khas yang dipengaruhi oleh beberapa faktor diantaranya, kebudayaan, adat istiadat, agama, dan kepercayaan, serta letak geografis daerah asalnya. Faktor kebudayaan akan melahirkan keunikan pada masing-masing senjata tradisional yang dapat terlihat pada tampilan fisiknya. Misalnya, terlihat dari nilai estetis bentuk serta ragam hias tradisional yang menghiasi senjata-senjata tersebut. Faktor kebudayaan dan adat istiadat melahirkan perbedaan tata cara pembuatan, material serta tata cara penggunaan senjatanya. Faktor agama dan kepercayaan menghasilkan perbedaan perlakuan masyarakat terhadap senjatanya masing-masing.

Di Indonesia, banyak terdapat senjata yang dianggap memiliki kekuatan non-fisik, magis, dan bersifat keramat yang mengharuskan senjata-senjata tersebut untuk diperlakukan dengan hormat. Misalnya, rencong di Aceh, mandau di Kalimantan, badik di Sulawesi Selatan, dan keris di Jawa. Karena kepercayaan masyarakat yang menganggap senjata-senjata tersebut memiliki kekuatan lain di luar kekuatan fisiknya, maka muncul sugesti dari dalam diri mereka, bahwa 
dengan membawa senjata-senjata tersebut maka mereka akan aman.

Keris merupakan salah satu senjata tradisional Indonesia yang telah dikenal oleh masyarakat luas. Nilai estetis dari sebilah keris menjadi daya tarik yang terbukti mampu mengumpulkan penggemar hingga ke pelosok tanah air bahkan mancanegara. Terdapat beberapa macam penggemar keris, ada yang mengkoleksinya 'hanya' karena tampilan fisiknya, dan ada pula yang mencintai keris karena tampilan fisik serta unsur non-fisiknya, yaitu kekuatan magis. Nilai kekuatan nonfisik yang dipercaya terkandung di dalam keris dianggap melebihi kekuatan fisiknya. Hal ini mengakibatkan kekuatan non-fisik tersebut dianggap begitu berharga sehingga melahirkan penghargaan yang mempengaruhi perlakuan masyarakat terhadap keris. Hingga saat ini, keberadaan kekuatan nonfisik tersebut masih menjadi polemik yang melahirkan beberapa perbedaan pendapat. Kepercayaan masyarakat terutama masyarakat Jawa akan kekuatan non-fisik keris tersebut merupakan fetisisme yang menarik untuk dibahas.

Keris, sebagai suatu alat yang dianggap pusaka oleh masyarakat Jawa, memiliki nilai-nilai simbolik yang mendalam. Oleh karena itu, penggunaan keris diatur dalam suatu etika tradisional tertentu. Seluruh aturan yang terkandung dalam etika penggunaan keris memiliki arti yang filosofis dan disesuaikan dengan kebutuhan praktis masyarakat sebagai pengguna keris. Para pengguna keris memiliki caranya masing-masing dalam menggunakan keris kepada pihak lain secara simbolik, hal ini pun mempengaruhi etika tradisional yang mengatur penggunaan keris. Penyesuaian lain yang terdapat dalam etika tradisional penggunaan keris disesuaikan dengan penyesuaian diri manusia terhadap lingkungannya. Segala penyesuaian itu pada akhirnya melahirkan perbedaan-perbedaan mengenai tata cara penggunaan keris, misalnya perbedaan letak dan arah dari keberadaan perabot keris tersebut. Segala perbedaan ini memiliki artinya masing-masing.

Penggunaan keris pada masa kerajaan Majapahit merupakan senjata yang umum digunakan oleh masyarakat dari berbagai kalangan sosial. Pada masa itu tidak ada seorangpun lakilaki yang berusia 12-80 tahun yang meninggalkan rumah tanpa menyelipkan keris pada sabuknya. Hal ini menunjukan bahwa keris telah digunakan sebagai senjata umum dan pelengkap pakaian masyarakat pada masa itu. Di setiap rumah masyarakat baik yang miskin hingga yang kaya, keberadaan keris merupakan sebuah kewajiban. Saat ini, di zaman yang serba modern, penggunaan keris masih mampu bertahan di tengahtengah masyarakat. Penggunaan keris pada zaman sekarang tentu mengalami pergeseran, yang semula keris digunakan hanya sebagai senjata tikam, pada saat ini keris digunakan dengan fungsi simbolik sebagai sebuah warisan keluarga, fungsi sosial 
sebagai sebuah senjata yang dipercayai oleh masyarakat memiliki kekuatan mistis dan sipat kandel, dan sebagai barang antik hasil karya kebudayaan yang berharga. Selain itu, keris pun digunakan sebagai pelengkap pakaian adat dan digunakan pada upacara-upacara tradisional. Kecenderungan pada masyarakat modern saat ini, keris merupakan simbol status sosial pada kalangan masyarakat menengah ke atas. Selain itu, karena dipercaya mengandung kekuatan mistis, keris digunakan sebagai pendukung nonfisik pada berbagai persaingan politik serta perdagangan. Di mancanegara, keris berfungsi sebagai barang antik dan perlengkapan resmi serta simbol nasional, hal ini terjadi di Negara Malaysia, Brunei Darussalam serta Thailand. Selain itu, di mancanegara keris pun digunakan untuk kepentingan studi dan ilmu pengetahuan, fungsi keris ini diterapkan di negara barat dan Jepang.

Hal yang menarik pada penggunaan keris pada era serba modern ini adalah bertahannya kepercayaan masyarakat akan kekuatan mistis yang dimiliki keris. Fetisisme semacam ini di masyarakat Indonesia banyak ditemukan dimana serangkaian upacara adat melibatkan berbagai unsur gaib.

\section{METODE PENELITIAN}

Metode yang digunakan pada penelitian ini adalah metode kualitatif. Langkah awal yang dilakukan adalah studi pustaka yang dilanjutkan dengan analisa. Analisa yang dilakukan merupakan pendapat dari sudut pandang penulis. Oleh karena itu, hasil penelitian ini merupakan kesimpulan dari analisa penulis mengenai objek kajian yang diangkat.

\section{BATASAN MASALAH}

Objek kajian yang diangkat adalah keris Jawa. Batasan masalah yang diangkat adalah kajian mengenai fetisisme masyarakat akan kemampuan magis yang dimiliki oleh keris. Pendekatan yang dilakukan pada objek kajian dilakukan melalui pendekatan dari segi antropologi. Hal ini berdasarkan pertimbangan pentingnya peranan kebudayaan terhadap perkembangan kepercayaan masyarakat terhadap kekuatan nonfisik yang terdapat di dalam sebilah keris. Kajian yang dibahas dikaitkan dengan fetisisme antropologi.

\section{STUDI PUSTAKA}

\section{Keris}

Keris termasuk kelompok senjata tikam. Menurut penelitian para ahli, senjata tikam hanyalah terdapat di Asia Tenggara, khususnya di kepulauan nusantara. Tetapi karena keadaan geografis kepulauan Nusantara yang terpisah satu sama lain, senjata tikam tadi mengalami perkembangan yang berbeda-beda..." (Hamzuri 1988 : h 1).

Keris memiliki tempat tersendiri di tengah masyarakat Jawa. Keris memperoleh pengaruh Hindu sehingga dapat dikatakan 


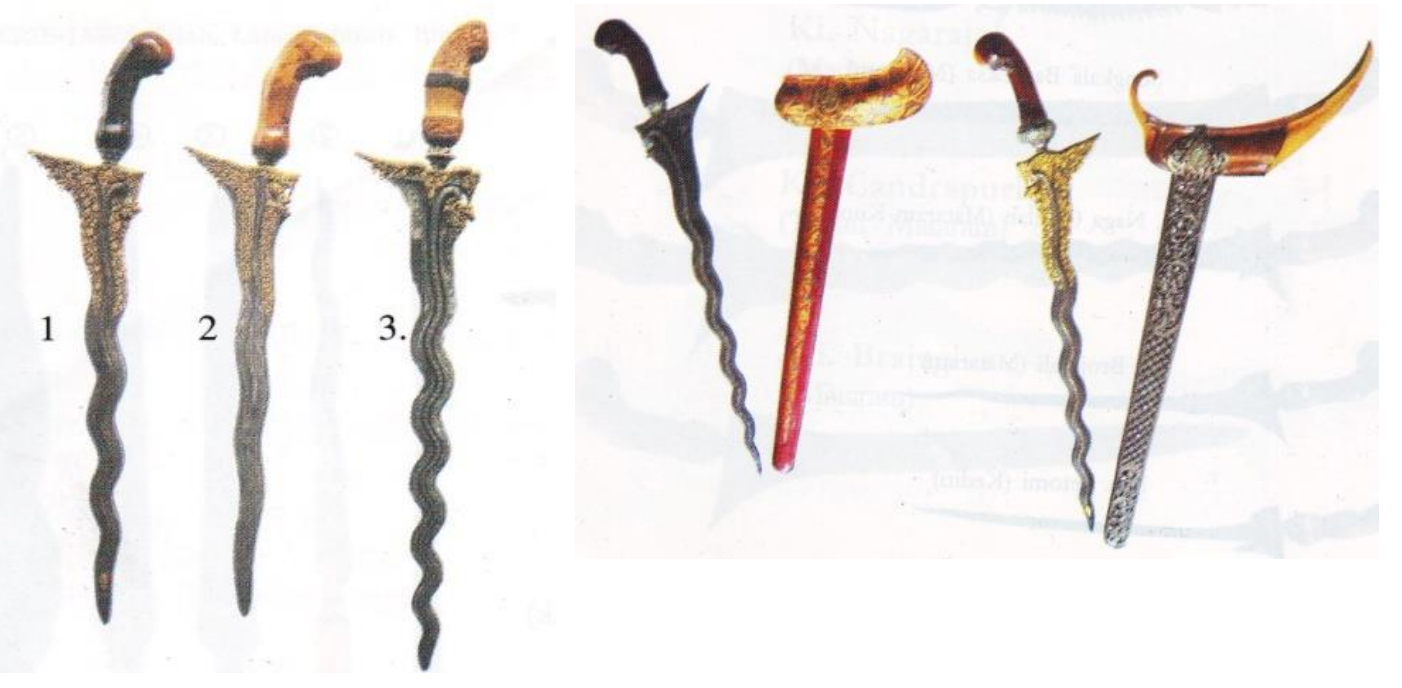

Gambar 1.(Kiri) Keris Luk : 1. Ki Ageng Pamekasan (Singosari); 2. Ki Brojolali (Mataram); 3. Sang Cakra Baskara (Mataram Kuno). (Kanan) Keris dan warangkanya (sarung keris). Sumber : Arifin, M.T. 2006. Keris Jawa, Bilah, Latar Sejarah, hingga Pasar. Jakarta. Penerbit : Hajied Pustaka

kemampuan magis yang dipercaya terkandung di dalamnya merupakan pengaruh dari agama tersebut.

Masuknya agama Islam ke nusantara tentu mempengaruhi sistem kepercayaan masyarakat akan kemampuan magis keris. Kerajaan Pajang merupakan salah satu kerajaan bercorak Islam pertama yang masih memiliki pengaruh Hindu di dalamnya, karena kerajaan Pajang termasuk kerajaan pedalaman yang tidak terlalu banyak menerima pengaruh dari luar. Kerajaan Mataram yang masih memiliki pengaruh Hindu dari kerajaan sebelumnya, yaitu kerajaan Pajang, memiliki kepercayaan besar terhadap benda keramat semacam keris. Dari sinilah keris berkembang dan memperoleh tempat khusus di tengah masyarakat. Keris memiliki arti, pesan moral serta simbol yang mendalam, nilai-nilai yang terkandung dalam keris ini disebut dengan istilah pasemon.
"Dalam konteksnya itu, unsur-unsur dan bahan-bahan pembuatan keris dianggap mengandung pesan moral dan etik, yang terkait dengan simbolisasi dari manunggaling kawulaGusti..." (Arifin, M.T. 2006).

Menurut Arifin (2006), pasemon yang berarti makna dan nilai simbolik yang dimiliki oleh sebuah keris merupakan simbolisasi dari manunggaling kawulaGusti yang terdiri dari,

1. Bentuk hubungan terluar atau 'kulit' antara bilah keris dengan warangka (sarung keris) merupakan simbolisasi kehidupan di dalam bebrayaning jagad ageng, sebagai pasemon pembentukan diri manusia yang dipengaruhi prosesproses sosio-kultural,

2. Hubungan yang lebih isoteris antara bilah keris dengan ganja (yang tertutup warangka), symbol dari hubungan Gusti dan kawula sebagai 'lorone sawujud lamun 
ingaran satunggal', dengan interpedensial yang tinggi 'ingaran ro kadiparan, pan sawiji jatinipun'.

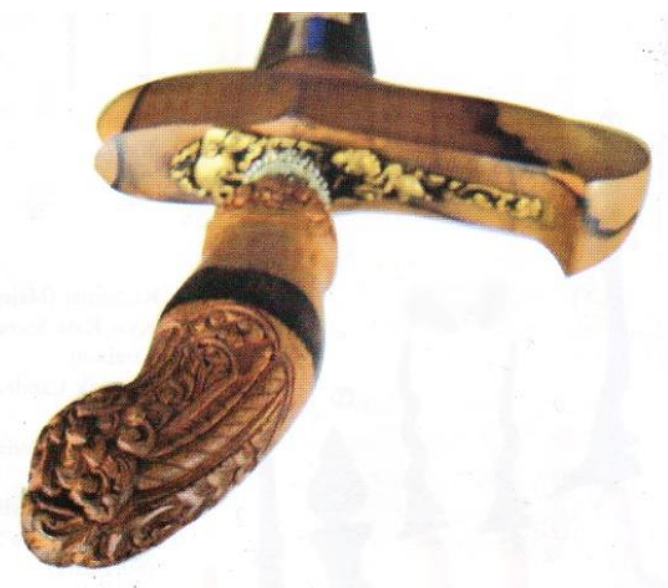

Gambar 2. Ukiran pada hulu keris. Sumber : Arifin, M.T. 2006. Keris Jawa, Bilah, Latar Sejarah, hingga Pasar. Jakarta. Penerbit : Hajied Pustaka

Bagian-bagian keris sendiri memiliki fungsi dan arti yang berbeda-beda. Misalnya sarung keris yang disebut warangka memiliki fungsi yang mendukung penampilan luar keris sebagai benda pusaka yang melengkapi pakaian adat ataupun upacara adat. Hal ini menyimpulkan bahwa perlengkapan keris sendiri memiliki arti dan fungsinya sebagai aksesoris keris. Fungsi dari aksesoris keris disebut busananing curiga. Sebagai aksesoris keris yang menentukan penampilan luarnya, aksesoris ini dilengkapi beragam hiasan dari batu dan logam mulia. Sebagai pusaka yang digunakan dalam berbagai peristiwa sosial, keris menjadi penentu simbol dan konteks sosial yang sangat penting. Oleh karena itu, penampilan keris yang terletak pada asesoris keris menjadi lebih penting dibandingkan bilah kerisnya sendiri.

Kedudukan keris dalam masyarakat memiliki berbagai arti, baik sebagai simbol sosial maupun fungsinya yang sangat mempengaruhi masyarakat secara psikologis. Dalam lingkungan istana atau keraton, keris merupakan benda pusaka yang menunjukan kebesaran, kedudukan serta pangkat. Selain itu, keris pun merupakan benda pusaka pelengkap upacara adat, pelengkap pakaian dalam upacara resmi keraton serta kelengkapan pakaian dalam pertunjukan kesenian. "Dalam upacara resmi kraton, baik raja maupun para sentana yang menghadap tentu memakai keris dengan wrangka Ladrangan...untuk kelengkapan pakaian sehari-hari, para sentana dan abdi dalam memakai keris wrangka Gayaman..." (Hamzuri 1988).

Dalam kehidupan masyarakat, pada masanya keris digunakan dalam berbagai aktivitas, misalnya dalam berbagai upacara adat, pernikahan, kelahiran dan khitanan. Penggunaan keris pada berbagai upacara tersebut digunakan juga oleh mereka yang membantu jalannya upacara, yang disebut sebagai sinoman. Dalam upacara adat, fungsi keris sebagai penolak bala agar setiap upacara berlangsung dengan baik tanpa gangguan apapun. Selain itu, dalam upacara pernikahan, keris yang digunakan oleh pengantin diberi ronce bunga melati yang juga berfungsi sebagai penolak bala. Masyarakat di pedesaan banyak yang membuat keris 
tiruan dari bambu lalu ditaruh di atas pintu sebagai penolak bala. Hal ini menunjukan besarnya kepercayan masyarakat terhadap kekuatan magis yang terkandung di dalam sebilah keris.

Kekuatan magis tersebut memiliki pengaruh yang baik juga pengaruh buruk bagi pemiliknya. Hal ini tergantung dari keadaan keris itu sendiri. Pamor keris atau gambar yang terdapat pada bilah keris memiliki daya magis yang berbeda-beda, begitu juga dengan daphur atau tipe keris itu sendiri. Pengaruh daya magis keris terlihat juga pada beberapa seni pertunjukan seperti wayang purwa (wayang kulit). Pada pertunjukan wayang kulit, keris tampil sebagai senjata yang digunakan untuk membunuh musuh. Dalam adegan
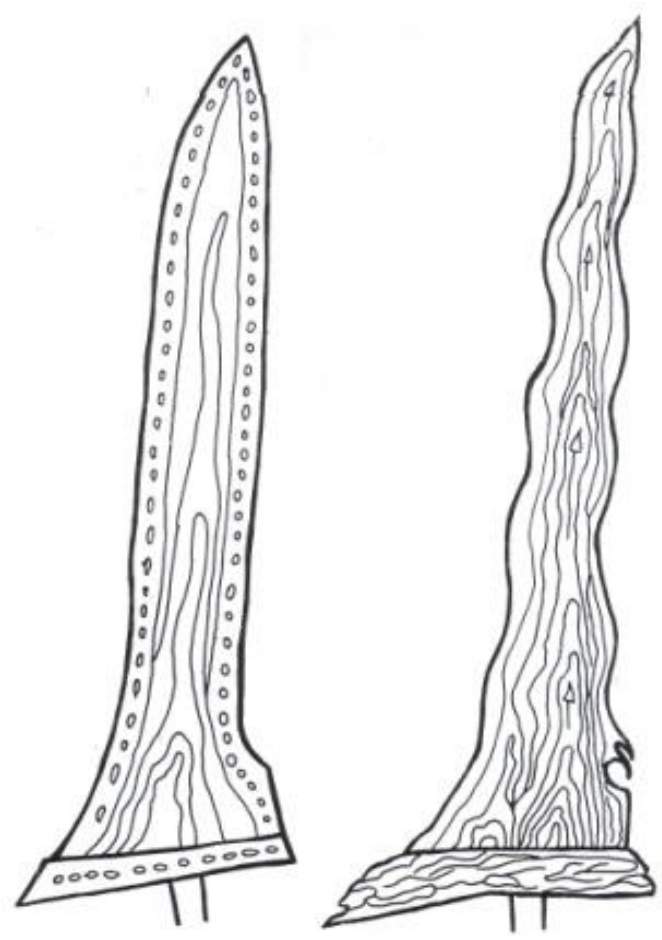

yang menceritakan musuh sulit dibunuh oleh senjata lain, maka keris tampil sebagai senjata sakti yang mampu membunuh musuh tersebut. Dalam pertunjukan lain seperti tari keris, wayang golek dan wayang orang, keris digunakan pula sebagai pelengkap pakaian dan juga sebagai senjata. Pada pertunjukan wayang orang, keris digunakan sebagai senjata hanya oleh para ksatria.

Keris yang memiliki kekuatan magis dapat dikatakan memiliki 'yoni' yaitu tuah atau kekuatan yang mengefektifkan fungsi dan angsar dari pamor keris. Yoni berhubungan dengan proses saat pembuatan, penjagaan, pengamanan atau maintenance serta keberadaan keris itu sendiri. Berikut merupakan beberapa cara dalam pembentukan yoni,

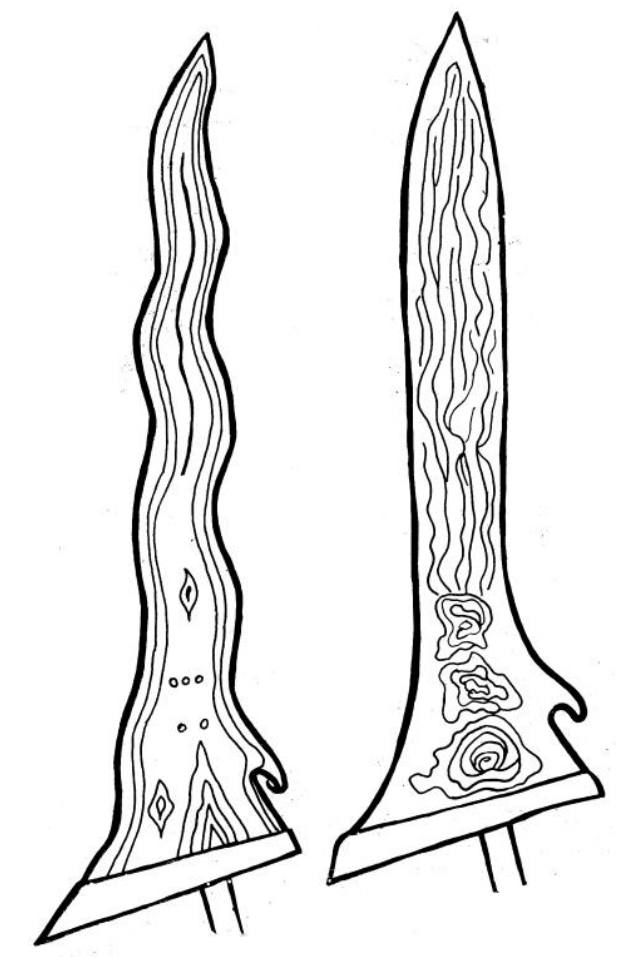

Gambar 3. Beberapa contoh pamor keris. Sumber : Hamzuri. 1988. Keris. Jakarta. Penerbit Djambatan. 
1. Yoni dapat terbentuk dari hubungan sang empu (pembuat keris) dengan Sang Khalik atau Sang Pencipta. Melalui hubungan ini, sang empu memanjatkan doa dan permohonan untuk pembentukan kekuatan pada keris yang dibuatnya,

2. Cara yang ke dua adalah dengan menginduksikan kemampuan empu pada keris yang dibuatnya. Cara ini disebut asmak atau semaan oleh kalangan santri,

3. Yoni atau kekuatan magis yang dimiliki keris dapat juga karena kehadiran makhluk halus di dalam keris itu sendiri. Makhluk halus ini berupa jin, arwah atau malaikat penjaga yang disebut khadam.

Terdapat cara khusus untuk mengetahui kemampuan serta fungsi yang terkandung dalam sebilah keris. Cara tersebut disebut dengan istilah tayuh keris. Tayuh juga merupakan cara untuk mengetahui keadaan dan asal pembuatan sebilah keris. Serta menelaah kecocokan antara karakter keris dengan pemiliknya. Tayuh hanya dapat dilakukan dengan kemampuan spiritual orang yang menayuh, prosesnya berlangsung dengan cara berkomunikasi dengan khadam yang terdapat di dalam keris. Proses komunikasi antara penayuh dengan khadam dilakukan secara batiniah.

"Sebenarnya tayuh itu merupakan bagian dari pengetahuan tradisional yang tumbuh dalam masyarakat Jawa, untuk mengetahui aspek esoteric dan kegunaan keris maupun senjatasenjata tradisional lainnya, yang sering dikenal dengan sebutan tajug." (Arifin, M.T. 2006).

Pengetahuan tradisional yang disebut tajug tersebut mencakup pasikutan yang digunakan untuk memperkirakan secara fisik akan tampilan kualitas bahan serta teknik pembuatannya serta maksud dari pamor akan kegunaannya bagi pemiliknya. Tajug juga meliputi pengetahuan laku dalam melakukan proses tayuh. Laku tertentu dalam melakukan proses tayuh harus dilakukan oleh penayuh yang biasanya diawali dengan proses sesuci, berpuasa ataupun puasa mutih, serta membaca amalan-amalan tertentu dengan tidak tidur dan menjauhi keramaian umum, setelah itu berbagai langkah yang telah ditentukan dalam serangkaian etika bertayuh baru bisa dilakukan. Seseorang yang telah memiliki tingkat kelimuan tertentu dapat langsung berkomunikasi dengan khadam yang terdapat di dalam sebilah keris hanya dengan mengangkatnya dengan tangan kiri. Proses tayuh lain yang dapat dilakukan oleh seseorang yang berilmu tinggi dapat pula dilakukan dengan cara menanyakan mengenai suatu keris pada khadam dari keris yang dimilikinya.

\section{Fetisisme}

Istilah fetisisme berasal dari kata fetish yang berarti sifat memuja (Strinati 2009 : h 102). Ada tiga konteks penggunaan istilah fetisisme, fetisisme antropologi, fetisisme seksual dan fetisisme komoditi. Fetisisme antropologi memiliki makna, setiap 
obyek yang dihuni oleh kekuatan tertentu (patung, jimat) yang disembah sebagai sesuatu yang memiliki sifat magis (Jean Baudrillard 1981). Adapun fetisisme seksual adalah gairah seksual seseorang yang dia terima dari sebuah dari obyek fisik, atau dari sebuah situasi tertentu (sumber:

https://psikologiabnormal.wikispaces.com/ Fetihism, diunduh pada 12 April 2016 pk.11:41 WIB). Fetisisme komoditi menurut Marx (Strinati 2009 : h 99), sifat produksi komoditi dalam sistem kapitalisme, di mana komoditi tidak semata dianggap sebagai benda guna (use value), akan tetapi sebagai obyek yang mengandung kekuatan daya pesona tertentu, yang memberikan status tertentu pada orang yang memakainya.
Kepercayaan masyarakat Indonesia terhadap kekuatan esortis yang terdapat pada sebuah benda, tumbuhan, hewan ataupun tubuhnya, yang dalam kajian ini berupa keris, dinamai oleh ahli barat sebagai dinamisme (dyna = tenaga, energi) (Malaka 1999 : h 310). Menurut Haviland, kepercayaan yang dipraktikan melalui pola perilaku dapat dimaknai sebagai agama, yang diusahakan oleh manusia untuk menangani masalah-masalah penting yang tidak dapat ditangani oleh teknologi dan teknik organisasi yang diketahuinya. "Karena dalam semua kebudayaan yang dikenal tidak ada sesuatu yang sungguh-sungguh dengan pasti dapat mengendalikan alam semesta, maka agama merupakan bagian dari semua

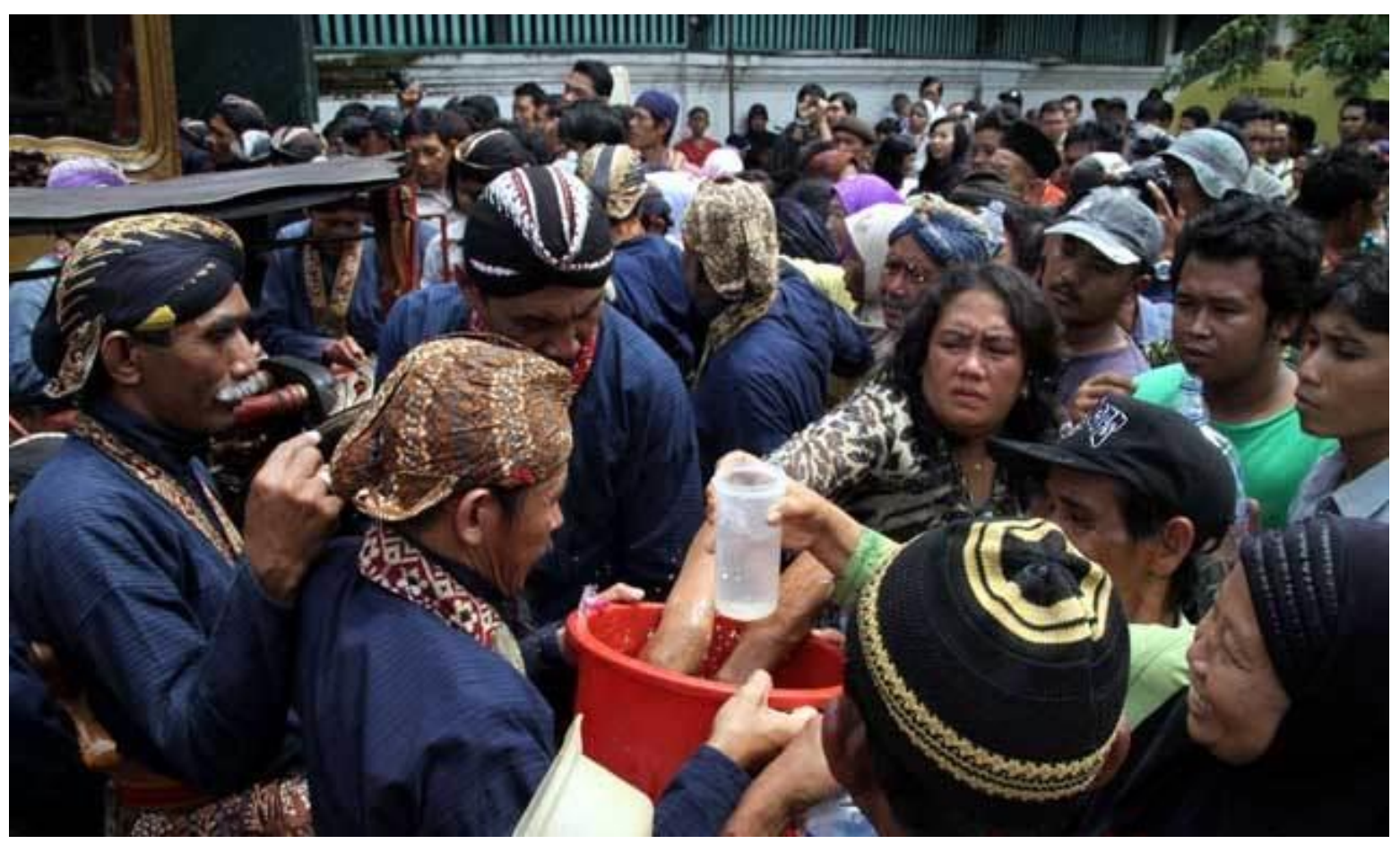

Gambar 4. Ribuan orang berebut air kembang sisa jamasan pusaka milik pura mangkunegaran. Sumber : http://metroonline.co/2014/10/ribuan-orang-berebut-air-jamasan-pusakamangkunegaran/ diunduh pada 14 April 2016 pk.10:25 wib 
kebudayaan yang telah bersama kita ketahui,"(Haviland 1985 : h 197). Berdasarkan uraian tersebut, fetisisme antropologi yang berarti pemujaan pada sebuah benda yang dianggap memiliki kekuatan magis merupakan praktik kepercayaan yang merupakan bagian dari kebudayaan.

\section{HASIL DAN ANALISIS}

Kemampuan atau kekuatan yang dipercaya terdapat pada sebuah keris dapat disimpulkan melalui skema 1. juga dari tuah yang diberikan empu terhadap pamor yang dibuat, selain itu seperti yang telah dijelaskan, spiritual yang dimilikinya pada keris yang ia buat. Tuah alami yang terdapat pada logam yang menjadi bahan dasar pembuatan keris pun dapat memberikan kemampuan magis. Ada yang menganggap kemampuan magis keris hanya sugesti belaka yang melahirkan fetisisme antropologi, yaitu kepercayaan berlebihan akan adanya kekuatan yang menghuni suatu benda. Polemik yang muncul akan kepercayaan pada kekuatan

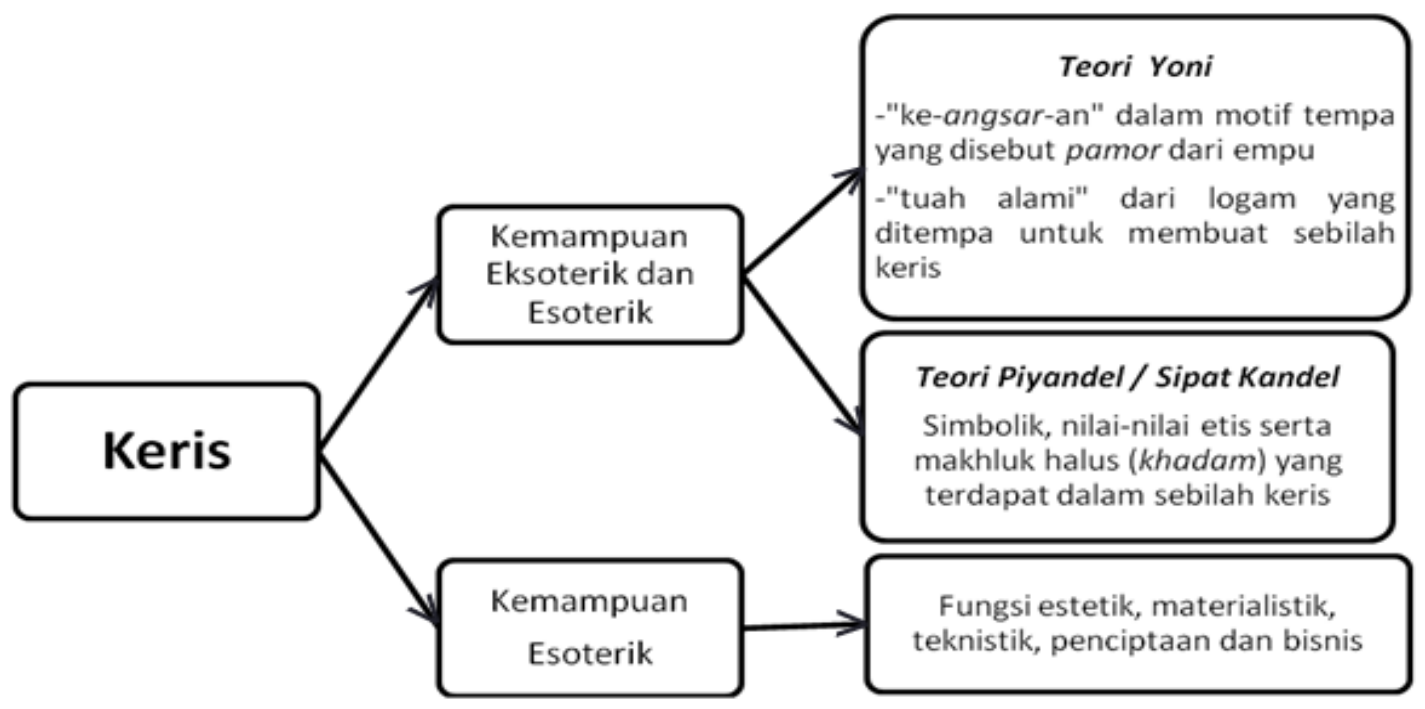

Skema 1. Kemampuan yang terkandung di dalam keris

Pada intinya, dalam teori piyandel menjelaskan mengenai penciptaan motif pamor yang dilakukan oleh seorang empu dapat menentukan mutu atau fungsi estetik dari sebuah keris. Lalu, dengan kehadiran khadam yang ditugaskan untuk menjaga pemilik keris, maka keris ini bertambah fungsinya menjadi lebih fungsional. Teori Yoni menjelaskan bahwa kekuatan non-fisik keris tak hanya dari kehadiran khadam, tetapi keris hadir dalam bentuk beberapa perbedaan pendapat. Berikut polemik tersebut dijelaskan dalam skema 2.

Kekuatan keris yang terbagi menjadi kekuatan fisik dan kekuatan non-fisik merupakan hasil persepsi masyarakat akan sebilah keris. Berbagai kepercayaan masyarakat akan keampuhan keris sebagai senjata dan benda keramat merupakan fetisisme antropologi yang bertahan di tengah 


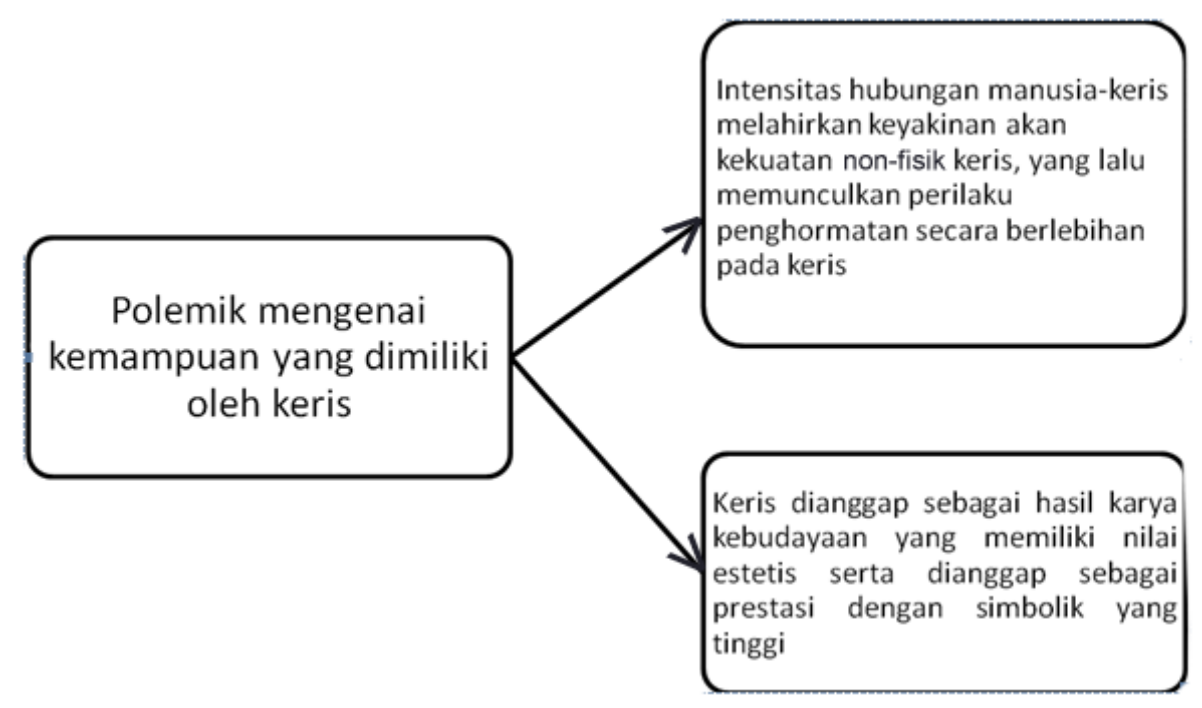

Skema 2. Polemik mengenai perbedaan pendapat akan kemampuan keris.

masyarakat Indonesia hingga saat ini, walau dengan berbagai pergeseran. Pergeseran fungsi keris yang awalnya hanya sebagai senjata tikam, berkembang menjadi benda pusaka keramat yang mampu menjaga pemiliknya dari segala marabahaya. Pada masa yang serba modern ini, keris masih dipercaya memiliki kemampuan magis yang mampu memberi dukungan non-fisik pada pemiliknya, dukungan ini digunakan pada beragam aktivitas seperti perdagangan, politik serta usahausaha manusia lainnya. Fetisisme antropologi semacam ini masih banyak dianut oleh masyarakat Indonesia. Prosesi jamasan keris yang biasa dilakukan pada malam satu suro, yaitu tahun baru Jawa, di pura mangkunegaran, Solo, Jawa Tengah adalah prosesi pemandian keris yang menunjukan keris sebagai benda fetis yang luar biasa diyakini oleh masyarakat Jawa. Air bekas memandikan keris diperebutkan karena dipercaya memiliki tuah yang dapat mendatangkan berkah. Mereka rela berdesak-desakan dan terinjakinjak demi memperoleh air jamasan untuk membasuh wajah dan dibawa pulang ke rumah. Dalam kasus ini air pun menjadi benda fetis. Kepercayaan masyarakat akan kemampuan yang hadir berkat keberadaan khadam di dalam keris, ditunjukan dengan berbagai penghormatan berlebihan. Hal ini terjadi karena masyarakat percaya keris harus diperlakukan sebaik mungkin agar khadam yang terdapat di dalamnya merasa 'betah'.

\section{KESIMPULAN}

Fetisisme antropologi yang berkembang di masyarakat Indonesia mampu bertahan hingga saat ini. Bahkan di era yang serba modern ini masih banyak ditemukan berbagai aktivitas yang memasukan unsur fetisisme. Kebudayaan melahirkan sistem kepercayaan, lalu kepercayaan menghasilkan sugesti akan kekuatan suatu benda, yang selanjutnya disebut 
fetisisme antropologi. Maka, keris dapat dikatakan sebagai benda fetis yang merupakan hasil karya kebudayaan masyarakat Indonesia, khususnya Jawa.

\section{DAFTAR PUSTAKA}

Arifin, M.T

2006 Keris Jawa, Bilah, Latar Sejarah, hingga Pasar.

Jakarta: Hajied Pustaka

Hamzuri

1988 Keris. Jakarta: Djambatan

Haviland, W. A

1985 Anthropology

Jakarta: Erlangga
Jean Baudrillard

1981 "Fetishism and Ideology", For a Critique of the Political economy of the Sign. Telos press

Malaka, Tan

1999 Madilog, Materialisme Dialektika Logika.

Jakarta: Pusat Data Indikator Strinati, Dominic

2009 Popular Culture, Pengantar Menuju Teori Budaya Populer. Yogyakarta: Ar-Ruz Media https://psikologiabnormal.wikispaces. com/Fetihism

http://metroonline.co/2014/10/ribuanorang-berebut-air-jamasanpusaka-mangkunegaran/ 